\section{§7. Theoretical Expressions for Removing Tritium from Exhaust Gas}

Kawano, T.

A tritium cleanup system for application to exhaust gases discharged from a large helical device has been developed. All the hydrogen including the tritium in the system is converted from its various chemical forms into molecules of hydrogen gas before removal. The system essentially consists of five components: a hydrogen separator, a decomposition-processing vessel, a hydrogen-absorbing vessel (Ti), a circular pump, and a buffer tank. The decomposition-processing vessel fulfills a very important role in decomposing various tritiated compounds and extracting tritium in the chemical form of hydrogen molecules.

In the previous study, the system's performance was tested based on computer simulations. In the simulations, the process gas was assumed to be made up of hydrogen and methane, where part of the hydrogen and methane had been tritiated. For expressing the removal of tritium in the simulations, two fundamental Eqs. (1) and (2) were used without any proof.

$\mathrm{P}_{\mathrm{Q} 2}(\mathrm{t}+\Delta \mathrm{t})=\mathrm{P}_{\mathrm{Q} 2}(\mathrm{t})+\frac{\mathrm{dP}_{\mathrm{Q} 2}(\mathrm{t})}{\mathrm{dt}} \Delta \mathrm{t}-2 \frac{\mathrm{dP}_{\mathrm{CQ} 4}(\mathrm{t})}{\mathrm{dt}} \Delta \mathrm{t}$

$\mathrm{P}_{\mathrm{CQ} 4}(\mathrm{t}+\Delta \mathrm{t})=\mathrm{P}_{\mathrm{CQ} 4}(\mathrm{t})+\frac{\mathrm{dP}_{\mathrm{CQ} 4}(\mathrm{t})}{\mathrm{dt}} \Delta \mathrm{t}$

Where, $\mathrm{P}_{\mathrm{Q} 2}(\mathrm{t})$ : Partial pressure of hydrogen $[\mathrm{Pa}]$ at time $\mathrm{t}$, $\mathrm{P}_{\mathrm{CQ} 4}(\mathrm{t})$ : Partial pressure of methane $[\mathrm{Pa}]$ at time $\mathrm{t}, \mathrm{t}$ : Stated time [hr], and $\Delta \mathrm{t}$ : Minimal elapsed time from stated time $\mathrm{t}$ [hr]. In this report, it will be shown how practical forms of both the differentiations in Eqs. (1) and (2) can be derived.

\section{(1) Differentiation: $\mathrm{dP}_{\mathrm{Q}_{2}}(\mathrm{t}) / \mathrm{dt}$ :} is given by

The speed of hydrogen separation in a given volume

$$
\frac{\mathrm{dV}_{\mathrm{Q} 2}}{\mathrm{dt}}=\mathrm{K} \mathrm{S}\left[(\text { Pin })^{1 / 2}-(\text { Pout })^{1 / 2}\right]
$$

Where, $\mathrm{V}_{\mathrm{Q} 2}$ : Volume of hydrogen in standard state $(273 \mathrm{~K}$, $0.1013 \mathrm{MPa})\left[\mathrm{Nm}^{3}\right], \mathrm{dV}_{\mathrm{Q} 2} / \mathrm{dt}$ : Speed of hydrogen separation $\left[\mathrm{Nm}^{3} / \mathrm{hr}\right], \mathrm{K}$ : Rate constant $\left[\mathrm{Nm}^{3} / \mathrm{hr} / \mathrm{Pa}^{1 / 2} / \mathrm{cm}^{2}\right]$, S: Area of membrane for hydrogen separation $\left[\mathrm{cm}^{2}\right]$, Pin: Absolute partial pressure of hydrogen at separator inlet $[\mathrm{Pa}]$, and Pout: Absolute pressure of hydrogen at separator outlet $[\mathrm{Pa}]$.

The residual volume of hydrogen at stated time $t$ is $\mathrm{V}_{\mathrm{Q} 2}$ when the standard state applies. Then, $\mathrm{P}_{0}$ is the pressure of the standard state $(0.1013 \mathrm{MPa}) . \quad \mathrm{V}_{\mathrm{B}}$ and $\mathrm{P}_{\mathrm{B}}$ are assumed to be the volume of the buffer tank regarded as the whole interior volume of the system and pressure when $\mathrm{V}_{\mathrm{Q} 2}$ has spread in the buffer tank at the stated time. Consequently, we obtain the following Eq. (4)

$$
\frac{\mathrm{dP}_{\mathrm{B}}}{\mathrm{dt}}=\left(\mathrm{P}_{0} / \mathrm{V}_{\mathrm{B}}\right) \mathrm{K} \mathrm{S}\left[(\text { Pin })^{1 / 2}-(\text { Pout })^{1 / 2}\right]
$$

This is the speed of hydrogen removal as a function of pressure. If we assume that the initial speed of separation is $\mathrm{Q}_{0}$, we obtain the following Eq. (5)

$$
\frac{\mathrm{dP}_{\mathrm{B}}}{\mathrm{dt}}=\frac{\mathrm{Q}_{0} \mathrm{P}_{0}}{\mathrm{~V}_{\mathrm{B}}}\left(\left(\frac{\mathrm{Pin}}{\text { Pin- } 0}\right)^{1 / 2}-\left(\frac{\text { Pout }}{\text { Pin-0 }}\right)^{1 / 2}\right)
$$

where, Pin- 0 and Pout- 0 are assumed to be initial partial pressures at the inlet and outlet of the separator.

Since $\mathrm{P}_{\mathrm{Q} 2}(0)$ and $\mathrm{P}_{\mathrm{Q} 2}(\mathrm{t})$ are partial pressures of hydrogen in the buffer tank for states at times 0 and $t, E q$. (5) becomes

$$
\frac{\mathrm{dP}_{\mathrm{Q} 2}(\mathrm{t})}{\mathrm{dt}}=-\frac{\mathrm{Q}_{0} \mathrm{P}_{0}}{\mathrm{~V}_{\mathrm{B}}}\left(\left(\frac{\mathrm{P}_{\mathrm{Q} 2}(\mathrm{t})}{\mathrm{P}_{\mathrm{Q} 2}(0)}\right)^{1 / 2}-\left(\frac{\mathrm{P}_{\mathrm{Ti}}}{\mathrm{P}_{\mathrm{Q} 2}(0)}\right)^{1 / 2}\right)
$$

This gives us the differential $\mathrm{dP}_{\mathrm{Q} 2}(\mathrm{t}) / \mathrm{dt}$ in Eq. (1). Where $\mathrm{P}_{\mathrm{Ti}}$ is about $1 \times 10^{-4} \mathrm{~Pa}$ that is a practically attainable pressure in actual vacuum system using titanium as hydrogen-absorbing materials.

\section{(2) Differentiation: $\mathrm{dP}_{\mathrm{CQ} 4}(\mathrm{t}) / \mathrm{dt}$}

Suppose that the gas for processing was in the buffer tank at an overall pressure of $\mathrm{P}_{\mathrm{T}}(\mathrm{t})$, a part of which was methane at a partial pressure of $\mathrm{P}_{\mathrm{CQ} 4}(\mathrm{t})$. That is, the gas for processing had a volume of $\mathrm{V}_{\mathrm{B}}$ at $\mathrm{P}_{\mathrm{T}}(\mathrm{t})$ and consisted of methane gas in $\mathrm{V}_{\mathrm{B}}$ and at $\mathrm{P}_{\mathrm{CQ} 4}(\mathrm{t})$ and other gas components in $\mathrm{V}_{\mathrm{B}}$ at $\left(\mathrm{P}_{\mathrm{T}}(\mathrm{t})-\mathrm{P}_{\mathrm{CQ} 4}(\mathrm{t})\right)$. The three volumes of the entire gas, methane, and other gas components should be same. The only difference is pressure. Therefore, the volume processed after circulation over a time interval of $\mathrm{dt}$ is also equal to the volume of methane processed over the same time interval. Assuming that the gas-flow rate is represented by $F\left(P_{T}(t)\right)$ $\left[\mathrm{m}^{3} / \mathrm{hr}\right]$ as a function of the total gas pressure, the volumes themselves processed after circulation over a time interval of $d t$ are $F\left(P_{T}(t) d t\right.$ for the entire gas, methane, and the other gas components and decomposed methane is $\mathrm{R}_{\mathrm{d}} \times \mathrm{F}\left(\mathrm{P}_{\mathrm{T}}(\mathrm{t}) \mathrm{dt}\right.$ (= $d V)$, where $R_{d}$ is the rate of decomposition. As a result, methane with volume $\mathrm{dV}$ disappears, which leads to decrease $\mathrm{dP}_{\mathrm{CQ} 4}(\mathrm{t})$ in the partial pressure of methane in the buffer tank. This change is represented by:

$$
\begin{gathered}
P_{\mathrm{CQ} 4}(\mathrm{t}) \times\left(\mathrm{V}_{\mathrm{B}}-\mathrm{dV}\right)=\left(\mathrm{P}_{\mathrm{CQ} 4}(\mathrm{t})-\mathrm{dP}_{\mathrm{CQ} 4}(\mathrm{t})\right) \times \mathrm{V}_{\mathrm{B}} \\
\mathrm{P}_{\mathrm{CQ} 4}(\mathrm{t}) \times \mathrm{R}_{\mathrm{d}} \times \mathrm{F}\left(\mathrm{P}_{\mathrm{T}}(\mathrm{t})\right) \mathrm{dt}=\mathrm{dP}_{\mathrm{CQ} 4}(\mathrm{t}) \times \mathrm{V}_{\mathrm{B}} \text { and } \\
\frac{\mathrm{dP}_{\mathrm{CQ} 4}(\mathrm{t})}{\mathrm{dt}}=-\frac{\mathrm{F}\left(\mathrm{P}_{\mathrm{T}}(\mathrm{t})\right)}{\mathrm{V}_{\mathrm{B}}} \times \mathrm{R}_{\mathrm{d}} \times \mathrm{P}_{\mathrm{CQ} 4}(\mathrm{t})
\end{gathered}
$$

Equation (8) represents the decreased speed that the partial pressure of methane drops to with the decomposition of methane.

Thus, we can estimate the respective partial pressures with Eqs. (1), (2), (6), and (8), if only definite values are assigned to $\mathrm{Q}_{0}, \mathrm{P}_{0}, \mathrm{~V}_{\mathrm{B}}, \mathrm{P}_{\mathrm{Q} 2}(0), \mathrm{P}_{\mathrm{CH} 4}(0), \mathrm{P}_{\mathrm{Ti}}, \mathrm{F}\left(\mathrm{P}_{\mathrm{T}}(\mathrm{t})\right)$ and $\mathrm{R}_{\mathrm{d}}$. 